\title{
Homeopathy as an alternative for asthma treatment
}

\author{
Cássia Virginia Garciaํ, Gabriela Veiga Vieira Mancio Bandeira², \\ Andreas Sebastian Loureiro Mendez ${ }^{1}$ \\ (1) Federal University of Pampa - UNIPAMPA, Uruguaiana, RS, Brazil \\ (2) Federal University of Rio Grande do Sul - UFRGS, Porto Alegre, RS, Brazil
}

\begin{abstract}
Background: Asthma is a chronic inflammatory disease characterized by a reversible obstruction and hyperactivity of inferior aerial treat [1]. It is responsible for lifestyle modification and, considering its high frequency, it became an important issue in the budget of health services around the world. Aspects like the lack of definitive results and presence of adverse effects, observed for traditional therapy, as well as the search for better quality of life have increased patients' interest for complementary and alternative medicines (CAM), being homeopathy one of the most cited [2]. In 2001, asthma was between the 10 diagnostics most treated by homeopaths in USA [3]. Aims: In this work, a qualitative research was made focusing the evaluation of the real contribution that homeopathy can represent for asthma patients and the role of pharmacist in this therapy. Methodology: databases such as Medline, Sciencedirect and Bireme were used to find scientific articles, applying the expressions "asthma", "homeopathy" and "complementary and alternative medicine". Results: At least six works demonstrate successful applications of homeopathic treatment in children or adults with asthma. The main benefits cited are the decrease of frequency and gravity of the crises, besides of some cure cases. Conclusions: Data available are still scanty about asthma homeopathic treatment. The few works found showed this kind of therapy is very adequate, mainly because of the emotional component of the disease, but also because it represents to be away from the adverse effects commonly related to the traditional therapy (e. g. corticoids). To ensure a correct therapy is being made, the pharmacist must be present and active in the patients' identification and documentation, giving them right orientations about the use and storage of homeopathic medicines, besides of stimulating a close and confidence relationship with the homeopath. Also, the manufacturing of remedies must be according to the official guidelines in order to guarantee their quality.
\end{abstract}

Keywords: homeopathy; asthma; complementary and alternative medicine; pharmaceutical attention

\section{References:}

[1] Rang H, Dale M, Ritter J, Flower R. Rang \& Dale Farmacologia. 6th ed. Rio de Janeiro (Brazil): Elsevier; 2007.

[2] Shaw A, Noble A, Salisbury C, Sharp D, Thomson E, Peter TJ. Predictors of complementary therapy use among asthma patients: results of a primary care survey. Health Soc Care Community. 2008; 16(2):155-164.

[3] Lois Doerr RN. Using Homeopathy for Treating Childhood Asthma: Understanding a Family's Choice. J Ped Nurs. 2001; 16(4): 269-276. 


\section{Homeopatia como uma alternativa para o tratamento da asma}

\section{RESUMO}

Introdução: a asma é uma doença inflamatória crônica caracterizada por uma obstrução reversível e uma hiper-reatividade das vias aérea inferiores [1]. É responsável por modificações no estilo de vida, e, considerando sua alta frequência, se tornou um problema importante no orçamento dos serviços de saúde pelo mundo. Aspectos como a falta de resultados definitivos e a presença de efeitos adversos, observados para o tratamento convencional, bem como a busca por melhor qualidade de vida têm aumentado o interesse dos pacientes por terapias alternativas e complementares, sendo a homeopatia uma das mais citadas [2]. Em 2001, a asma estava entre os 10 diagnósticos mais tratados pelos homeopatas nos Estados Unidos [3]. Objetivos: neste trabalho, uma pesquisa qualitativa foi realizada, objetivando avaliar a real contribuição que homeopatia pode representar para os pacientes com asma e o papel do farmacêutico neste tratamento. Metodologia: as bases de dados Medline, Sciencedirect e BIREME foram usadas para encontrar artigos científicos, aplicando as expressões "asma", "homeopatia" e "terapias alternativas e complementares. Resultados: pelo menos seis trabalhos demonstram aplicações de sucesso da homeopatia no tratamento de adultos ou crianças com asma. Os principais benefícios citados são a diminuição da frequência e da gravidade das crises, além de alguns casos de cura. Conclusões: Os dados ainda são escassos em relação ao tratamento homeopático da asma. Os poucos trabalhos encontrados mostraram que esse tipo de terapia é muito adequada, principalmente pelo componente emocional, mas também por ser livre de efeitos adversos, muito comuns no tratamento convencional (por exemplo, corticoides). Para assegurar que um tratamento correto está sendo feito, o farmacêutico deve estar presente e ativo na identificação e documentação dos pacientes, dando-lhes orientações corretas sobre o uso e o armazenamento dos medicamentos homeopáticos, além de estimular um relacionamento próximo e de confiança com o homeopata. Da mesma forma, a preparação dos medicamentos deve estar de acordo com as guias oficiais a fim de garantir a sua qualidade.

Palavras-chave: homeopatia; asma; medicina alternativa e complementar; atenção farmacêutica.

\section{(cc) BY-NC-ND Licensed to GIRI}

Support: authors declare that this study received no funding

Conflict of interest: authors declare there is no conflict of interest

Correspondence author: Cassia Virginia Garcia, cassiavgarcia@yahoo.com.br, www.unipampa.edu.br

How to cite this article: Garcia CV, Bandeira GVVM, Mendez ASL. Homeopathy as an alternative for asthma treatment. Int J High Dilution Res [online]. 2011 [cited YYYY Month dd]; 10(36): 201-202. Proceedings of the XXV GIRI Symposium and VIII CBFH; 2011 Sep 04-07; Foz do Iguaçu (Brazil). GIRI and ABFH; 2011; Available from: http://www.feg.unesp.br/ ojs/index.php/ijhdr/article/view/461/481 